\title{
The machination of foreign direct investment flow to emerging markets - a focus on Africa
}

\author{
Rafiu Adewale Aregbeshola \\ Department of Business Management, \\ College of Economic and Management Sciences, \\ University of South Africa, Pretoria, South Africa
}

\begin{abstract}
Purpose - The deterministic role of various macroeconomic fundamentals on the attractiveness of countries to inflow of FDI is well documented in literature. The role of market size, infrastructural development, inflation and exchange rates differential have been supported as determinants of FDI direction. However, no documented study has benefited from diverse measures of institutional adequacy as presented in this study. The paper aims to discuss these issues.

Design/methodology/approach - The paper adopts various econometric approaches that include descriptive statistics, fixed effects models, LM test of independence, feasible generalised least squares regression and SUR estimations.

Findings - This study unveils the specific impacts and explanatory power of each of the variables along country lines, and the author compares the results of some emerging markets in Asia, Eastern Europe, and South America to some selected countries in Africa. Using data set from various sources over a period of 44 years in a seemingly unrelated regression environment, this study suggests that poor technological capability, inadequate political system, weak productivity gains are major deterrents to the attractiveness of African countries to inflow of FDI.

Research limitations/implications - The major limitation of this study revolves around availability of usable data, which compels the researcher to limit the focus and the span of time series.

Practical implications - The study suggests the need to improve institutional quality in emerging economies, especially countries in Africa in order to enhance their attractiveness to FDI inflow. More importantly, the study found that low capital productivity gains hinder the attractiveness of African emerging markets to FDI inflow.

Social implications - To alleviate poverty, attraction of FDI is considered important, and the improvement of institutional functionality in that regard is found to be important. The need to augment technological improvement is considered very important and critical.

Originality/value - This serves to confirm that the article entitled "The Machination of Foreign Direct Investment Flow to Emerging Markets - A focus on Africa" is my own original work, envisaged to contribute to the debate about the role of macroeconomic fundamentals, especially capital productivity gains as determinants of a country's attractiveness to inflow of foreign capital in academic literature. All the sources used and consulted have been fully acknowledged by a way of complete referencing. The author hereby agrees to the terms and conditions as stipulated by the publisher and the editorial board of this prestigious journal.
\end{abstract}

Keywords Technological capability, Foreign direct investment, Cross dependency, Emerging markets, Africa, Institutional adequacy

Paper type Research paper

Introduction and background knowledge

Various studies have documented the benefits of FDI to the host economies. The possibility of galvanising industrial development and concomitant employment opportunities has been of particular interest, especially in the developing countries (Alfaro et al., 2004). This improvement in the production capacity have translated into augmenting the quality of final products at reduced production costs, and by extension, making the products affordable to the poor communities (Vladimir et al., 2013). In addition, access to a series of cutting-edge but cheaper technological capabilities have enabled easy access to state-of-the-art healthcare JEL Classification - C13, C23, D22, F23 
DOI to the article: https://doi.org/10.1108/AJEMS-12-2017-0313

AJEMS products and facilities, which has helped to increase life expectancy, especially in the underdeveloped poor communities. Furthermore, domestic businesses have benefited from improvement in operational processes and administrative expertise through their integration and corroboration with the subsidiaries of foreign firms (Baer and Rangel, 2001; Bénassy-Quéré et al., 2007).

However, there has been inconclusive evidence on the determinants of FDI direction by multinational corporations (MNCs). While extant literature emphasises the importance of market size (Chousa et al., 2008), others have signalled to the importance of infrastructural facility (Akinkugbe, 2005). In some other studies, the role of institutional framework has been documented (La Porta et al., 2000), while labour dynamics was investigated by Olney (2013). In addition to the established variables, the importance of domestic capital markets has been added to the body of knowledge as strong determinants of FDI (Vladimir et al., 2013).

Although, most of the studies cited above investigated the underlying determinants of FDI direction, there is clear divergence on the findings of the studies as informed by methodological divergence and coverage. Further, the studies are largely regional (Bénassy-Quéré et al., 2007; Chousa et al., 2008) or country-specific (Baer and Rangel, 2001; Olney, 2013; Vladimir et al., 2013). This study fills academic lacuna by combining a wide range of variables that have previously been disjointedly adopted or ignored in academic literature. Furthermore, although the findings of previous studies are not considered inaccurate, the variation in the findings, especially along country/regional-dichotomy, essentially where similar empirical approaches were adopted, motivates the need to expand the focus of academic study on this important area of research interest both conceptually and methodologically. To that effect, this study uncovers the effects of various variables on FDI behaviour in emerging markets, especially by combining rapidly developing economies and juxtaposing them against less developed/emerging ones, and by adopting very different methodological approaches.

\section{International capital flows and investment}

Attraction of investments by MNCs has become an indispensable part of national economic strategy of both the developed and emerging economies (Stiglitz and Charlton, 2005; United Nations Conference on Trade and Development (UNCTAD), 2016). As a result, institutional supports are galvanised by political leaderships to attract operational subsidiaries of MNCs (Akinkugbe, 2005). Hence, the flow of FDI has continued to increase over the past decades. The global flow of FDI was quoted at \$650bn between 1970 and 1980, more than six times its value of \$105bn in 1967 (United Nations Conference on Trade and Development, 2013, p. 16). According to UNCTAD (2016, p. 5), the flow of FDI reached a new height in 2015 with an increase of 37per cent from 2014 statistics. According to the same source, the developing countries of Asia accounted for about 35 per cent of the global flow in 2015, while Africa, Latin America and the Caribbean lost more than 32 and 11 per cent divestment, respectively. This dynamic is further explained in Table I.

Table I.

Growth rates of global GDP, GFCF, trade, employment and FDI 2008-2016 (per cent)

\begin{tabular}{lrrrrrrrrl}
\hline Variables & 2008 & \multicolumn{1}{c}{2009} & 2010 & 2011 & 2012 & 2013 & 2014 & 2015 & 2016 \\
\hline GDP & 1.5 & -2.0 & 4.1 & 2.9 & 2.4 & 2.5 & 2.6 & 2.8 & 3.1 \\
Trade & 3.0 & -10.6 & 12.6 & 6.8 & 2.8 & 3.5 & 3.4 & 3.7 & 4.7 \\
GFCF & 3.0 & -3.5 & 5.7 & 5.5 & 3.9 & 3.2 & 2.9 & 3.0 & 4.7 \\
Employment & 1.2 & 1.1 & 1.2 & 1.4 & 1.4 & 1.4 & 1.3 & 1.3 & 1.2 \\
FDI & -20.4 & -20.4 & 11.9 & 17.7 & -10.3 & 4.6 & -16.3 & 11.4 & 8.4 \\
FDI values (Trillion US \$) & 1.49 & 1.19 & 1.33 & 1.56 & 1.40 & 1.47 & 1.23 & 1.37 & 1.48 \\
Source: Adapted from UNCTAD(2016) & & & & & & & & \\
\end{tabular}


As contained in Table I, the year 2010 has been particularly very good for most of the measures of global wealth. In that year, global GDP recuperated from 2009 loss of about 2 per cent and grew by 4.1 per cent; trade also rallied from 2009 loss of -10.6 per cent and grew by almost 13 per cent; while gross fixed capital formation convalesced from a loss of -3.5 per cent and grew by 5.7 per cent. For most of the other years, the percentage increase in inflow and stock of FDI has continuously outperformed other measures of global wealth.

\section{Drivers of FDI}

Studies (Kolstad and Villanger, 2008; Olney, 2013) have proposed and adopted different measures to explain the criteria adopted by MNCs when choosing offshore subsidiaries. While the divergence in methodologies applied has also yielded divergent results, there is an understanding that the determinants of attractiveness of countries to inflow of FDI varies widely along country/regional lines. However, most of the studies lend credence to the explanatory properties of capital productivity gain as a determinant of a country's attractiveness to inflow of FDI (Chakrabarti, 2003; Kok and Ersoy, 2009). In the opinion of Chung (2001), MNCs act strategically when it comes to overseas expansion. Evidence of this strategic approach was buttressed in a few previous studies (Bruce and Chang, 1991; Robert and Papanastassiou, 1999) where it was found that investor motives are functions of favourablemacroeconomic conditions.

\section{The new thinking}

Although, previous studies have emphasised the importance of institutional framework on FDI behaviour (especially in emerging economies) (Chakrabarti, 2003), capital market development also have a high predictive ability, especially in the African context (Aregbeshola, 2016). Conversely, practical realism suggests that some countries without institutional adequacy or fledgling capital markets have been attractive to FDI inflow at the expense of more relatively developed markets. While academic propositions serve as the theoretical basis for offshore expansion, realities defy categorical accuracy of the identified determinants, especially in many emerging economies.

From the foregoing, it becomes important to expand existing literature on the determinants of the direction of FDI, especially by adopting more robust explanatory variables as well as revisiting the econometric approach. We therefore underpin this study with the costly state-verification model (CSV) of Townsend (1979). According to Townsend, information arbitrage, which is a bye-product of poor disclosure depicts institutional weakness. The author further suggests that incidence of information arbitrage would reduce as markets develop, thereby reducing the cost of capital. In addition, enforceability of contracts and institutional efficiency are incorporated into this model by Kolstad and Villanger (2008).

However, the historical trend of FDI flows to emerging markets suggests that most countries that attracted the bulk of FDI neither had strong institutional framework, nor efficient capital markets at the time. For instance, when the industrial revolution of China began in the early nineteenth century, evidence of institutional weaknesses was conspicuous and the capital market was fledgling (Puffer et al., 2009). In the face and depth of institutional weaknesses as well as infrastructural gap experienced, the country was considered attractive to FDI flow. A study of Russian economy during the early industrialisation periods supports the weakness in the explanatory power of institutional apparatus (Loungani and Mauro, 2001), especially given that institutional deficiency in Russia did not hinder its attractiveness to inflow of FDI (Paul, 1982; Puffer et al., 2009).

In Latin America, Brazil witnessed noticeable levels of FDI inflow into the public sectors both prior and after the Second World War. The service sector also benefited, 
DOI to the article: https://doi.org/10.1108/AJEMS-12-2017-0313

AJEMS

in spite of the conspicuous weaknesses in macroeconomic fundamentals in the economy (Taylor and Buranelli, 2007). At a point, at least 400 of the 500 largest global MNCs that originated from the USA, Canada and the UK invested in infrastructure development of Brazil (Baer and Rangel, 2001, p. 95). It must be recalled that Brazil witnessed one of the highest levels of inflation in history, and the process of reversing its effects hampered labour market efficiency that is considered important to attract FDI by Durevall (2012), as well as Olney (2013). Further, corruption was rife and FDI flew into Brazil in the face of unchequered graft (Taylor and Buranelli, 2007). The experience of Mexico was also similar, where a series of macroeconomic instabilities created infrastructural gap, which did not discourage the attractiveness of Mexico to inflow of FDI (Aizenman, 2003). The socio-political and economic arrangements of countries synoptically surveyed above are not very different from the case of African countries over the past decades.

However, while countries discussed in the preceding paragraphs have continuously been attractive to inflow of FDI, countries in Africa have failed to garner such strength of attractiveness. It is therefore important to expand academic searchlight beyond the established measures of institutional efficiency and the attractiveness of countries (especially countries in Africa) to FDI flow, which is the main contribution of this study to the body of academic literature, coupled with the expanded econometric approach and our conceptual distinction.

To that extent and in conjunction with Townsend's CSV model, we adopt Mill's Method of Residue (Mill, 1854). This model proposes that residue factors that have not been tested in the previous studies may better explain the real phenomenon. The model further suggests that the linkage between cause and effects do vary widely between and among contextual considerations. The model is deemed appropriate in this study as we juxtapose the intricacies of the attractiveness of developing countries in Asia, South America and Eastern Europe with African countries. The study strives to uncover other factors or processes that may explain weak attractiveness of emerging markets, especially those in Africa, to FDI inflow as compared to the other emerging markets.

\section{Research approach}

This study is set out to investigate the extent to which various institutional elements determine the attractiveness of countries in emerging markets to FDI inflow. To gauge the strength of institutional adequacy proposition documented in literature, we analyse the attractiveness of China, South Korea, India, Russia, Brazil, Mexico and major economies in Africa (Nigeria, South Africa, Egypt and Kenya). The choice of these economies is based on their attractiveness to inflow of FDI, coupled with being the regional economic powerhouses. Documented evidence (UNCTAD, 2016) identifies these economies as the consistently largest recipients of FDI in their geographical categories over the past decades.

To investigate the explanatory power of institutional apparatus, we modify the methodological approach of Asiedu and Lien (2011). In the investigation of possible role of political system and resource endowment on FDI inflow, these authors adopted a linear dynamic panel-data model. In their estimation, attempt was made to distinguish between institutional efficiency and democratic rules, and they focussed their study on the latter (and expanded by Olney, 2013) - in contrast to the focus of this study on the former.

In this study, we benefit from the measures of institutional efficiency such as polity score (Polity), corruption perception (Corpt), regulatory quality (Rglql) and the rule of law (Lawrl) to capture the efficiency and strength of state's regulatory instrument (Laeven and Majnoni, 2004). Our models include poverty rates/prevalence (pvrty) and civil liberty (Civbt). We included poverty and civil liberty in our models because of ideological proposition that poverty and civil liberty are strong indicators of human development and social peacefulness (Sen, 1999), which are essential to attract FDI inflow. 
Further, we introduced trade openness (Trdop) to test the support of government for FDI attraction (Olney, 2013), as well as inflation (Inflt) and measures of exchange rates volatility (Exgrt) to gauge macroeconomic fiscal and monetary stability (Ayaydin and Baltaci, 2013) In addition, we adopted gross fixed capital formation (Gfcfm) and telephone lines (Tlphl) as measures of infrastructural development (Laeven and Majnoni, 2004; Lee and Chang, 2009). It is proposed that the formation of these expansive models that have been underrepresented in previous studies may help uncover the real (as well as the strength of the) determinants of FDI inflow to some of the leading emerging economies in Asia, Eastern Europe and South America as opposed to the experience of leading economies in Africa. The full definition and sources of data set are presented in Table AI.

\section{The data and variables}

As indicated in the previous paragraphs, the variables used in this study have been used in some of the previous studies. However, there is no single study that has included all these variables as measures of country's attractiveness to inflow of FDI. The robustness of this study is primed on the depth of explanatory (and control) variables employed, the methodological strength as well as the richness in the scope of the study (with specific reference to comparing various emerging markets against some countries in Africa).

The dependent variable is stock of FDI as a percentage of GDP as adopted in some previous studies (Alfaro et al., 2004; Asiedu and Lien, 2011). Although, the stock of FDI has been used by some authors (Bénassy-Quéré et al., 2007), the GDP imperative is considered suitable because it captures the contribution of FDI to the GDP of economies under consideration. The independent variables are a pool of measurable indicators of institutional adequacy and capital productivity gains as suggested in the preceding paragraphs, which include civil liberty (Civbt) and freedom from corruption index (Corpt). Civil liberty measures the level of respect for human rights, while freedom from corruption index measures the extent to which the civil servant solicits illegal payment/bribes before discharging their official duties. We also tested the impact of respect for the rule of law (Lawrl) in our estimations. Respect for the rule of law is considered important as a measure of separation of powers between the tiers of government, as well as an indication of institutional efficiency.

The data generation exercise was very challenging, especially because the data set was generated from various sources. For instance, the data for FDI, exchange rates, fixed telephone subscriptions per 100 people, inflation and gross fixed capital formation were extracted from the World Development Indicators (World Bank database). Indices such as polity score was extracted from Centre for Systemic Peace (INSCR), while civil liberty was extracted from Freedom House database. Further, we extracted data set for poverty level from Brookings Global Data for Indices, while the data set for freedom from corruption was extracted from index of economic freedom (Econ Stats).

In addition, data set for regulatory quality and the rule of law were extracted from the World Governance Indicators, and trade openness was extracted from Economic Freedom of the World database. The data generating exercise was compounded by the fact that data set for Russia is only available from 1992 onward, and the 1970-1991 were generated through standard derivative approach from USSR data set on assumption that it was the largest economy in the Union. It is also important to note that most of the models exhibited a few missing units. To achieve balanced panel[1], five-year moving averages (forward and backward - as the case may be) were adopted.

\section{Baseline regression}

This study is set out to examine the deterministic properties of institutional variables to inflow of FDI in selected emerging economies. We specifically compare the importance of 
DOI to the article: https://doi.org/10.1108/AJEMS-12-2017-0313

AJEMS this set of variables on FDI behaviour in African countries to the more attractive emerging markets. To achieve this objective, we remodel Asiedu and Lien's (2011) benchmark model:

$$
\mathrm{FDI}_{i t} 1 / 4 \mathrm{a}_{1} \mathrm{pa}_{2} \mathrm{INST}_{i t} \mathrm{pa}_{3} X_{i t} \mathrm{pe}_{i t} \text {; }
$$

where FDI is stock of FDI as a percentage of GDP; INST represents institutional variables; and $X$ represents control variables; $i$ denotes countries and $t$ represents time; $\varepsilon_{i t}$ is the error term.

To estimate the baseline equation, we first conduct descriptive statistics to establish the distribution pattern of the data as part of our diagnostic approaches. From this analysis, we considered Skewness and Kurtosis, as well as the Jarque-Bera statistics. These measures are emphasised as the basic indicators of distribution pattern, which is an important assumption in statistical analyses. The result of the descriptive statistics is presented in Table II.

According to Table II, the test of normal distribution for all the variables is statistically significant at 1 per cent. In exception of inflation (Inflt), trade openness (Trdop), and freedom from corruption index (Corpt), the rest variables exhibit moderate dispassion from the mean. The skewness and Kurtosis statistics suggest moderation (both negative and positive). Further, the Jarque-Bera statistics reflect some moderation for most of the variables, more specifically, the indices. In the face of weak traces of skewness in the data behaviour, we do not reject the null hypothesis of normal distribution, essentially given the statistical significance of all the variables at 1 per cent.

\section{Empirical models}

Two separate models are estimated. The first model estimated is model 2, which is the augmented form of the baseline model that incorporates the measurable indicators of the regulatory formulation. This model tests the impact of regulatory quality on the attractiveness of the sampled countries to inflow of FDI. In that model, we introduced civil liberty, rule of law, regulatory quality and combined polity score. In addition, we retained trade openness as measures of trade liberalisation as well as telephone lines as a measure of technological advancement - both as control variables. Telephone lines is preferred to mobile penetration because it supports better internet speed through local area network, which is more secure and faster than Wi-Fi connectivity (Huang and Wang, 1995; Horak, 2007). Equation (2) is presented as follows.

Model on regulatory formulation:

$$
\mathrm{FDI}_{i t}{ }^{1 / 4} \mathrm{~b}_{0} \mathrm{pb}_{1} \mathrm{Civbt}_{i t} \mathrm{pb}_{2} \operatorname{Lawrl}_{i t} \mathrm{pb}_{3} \mathrm{Rglql}_{i t} \mathrm{pb}_{4} \mathrm{Polity}_{i t} \mathrm{pb}_{5} \operatorname{Trdop}_{i t} \mathrm{pb}_{6} \operatorname{Tlphl}_{i t} \mathrm{pe}_{i t} \text { : }
$$

Model 3 tests the interaction of capital productivity gains and attractiveness of countries to inflow of FDI. To achieve this, we augment the production function of Cobb and Douglass (1928).

Table II.

Descriptive statistics

\begin{tabular}{|c|c|c|c|c|c|c|c|c|}
\hline Variables & Mean & Median & SD & Skewness & Kurtosis & Jar.-Bera & Prob. & Obs. \\
\hline FDI & 3.2809 & 1.0235 & 6.39720 & 3.31511 & 15.22816 & $3,627.897$ & 0.0000 & 450 \\
\hline Gfcfm & 13.6528 & 7.2101 & 16.4379 & 1.54285 & 4.527870 & 222.3001 & 0.0000 & 450 \\
\hline Lawrl & -0.31339 & -0.2509 & 0.741089 & 0.55449 & 3.581411 & 29.39844 & 0.0000 & 450 \\
\hline Polity & -0.46888 & 4 & 12.91069 & -4.78758 & 33.11658 & $18,725.485$ & 0.0000 & 450 \\
\hline Inflt & 46.6229144 & 21.432218 & 206.04806 & 10.265843 & 114.93904 & $242,848.139$ & 0.0000 & 450 \\
\hline Tlphl & 6.9963020 & 6.5222938 & 4.6053707 & 0.8741575 & 4.2184234 & 85.146777 & 0.0000 & 450 \\
\hline Trdop & 99.5775385 & 7.7529166 & 263.67614 & 3.1492210 & 11.95213 & $2,246.4573$ & 0.0000 & 450 \\
\hline Exgrt & 1.83568789 & 1.941939 & 0.45771023 & -3.403171 & 14.270901 & $3,250.4911$ & 0.0000 & 450 \\
\hline Civbt & 4.14888888 & 4 & 1.3975993 & 0.1255973 & 2.1099905 & 16.035293 & 0.0000 & 450 \\
\hline Corpt & 48.56733333 & 31.75 & 250.11210 & 18.371508 & 355.78882 & 2,358,937.6 & 0.0000 & 450 \\
\hline Rglgl & 0.023776256 & -0.266615 & 0.7364887 & 0.7638277 & 4.0249007 & 63.452869 & 0.0000 & 450 \\
\hline Pvrty & 0.573022222 & & 0.3209780 & -0.129308 & 1.6470233 & 35.576776 & 0.0000 & 450 \\
\hline
\end{tabular}
1970-2014

'This article is $@$ Emerald Group Publishing and permission has been granted for this version to appear here (please insert the web address here). Emerald does not grant permission for this article to be further copied/distributed or hosted elsewhere without the express permission from Emerald Group Publishing 
In the original model, these authors suggested that optimal production system yields more than arithmetic increase in resource combination. In that thesis, it was further suggested that optimal utilisation of labour and capital creates superior output and utility. Through our remodel exercise, we included measures of exchange rates volatility, freedom from corruption, gross-fixed capital formation, headcount ratio of population living on less than US\$5/day (prevalence of poverty), and consumer price index. We further retain trade openness and number of fixed telephone subscriptions per 100 people as done in model 2. Building institutional dimension into the Cobb and Douglass model, we propose the following production function.

Remodelled production function (Cobb and Douglass, 1928):

$$
\begin{gathered}
\text { FDI }_{i t}{ }^{1 / 4} \mathrm{~b}_{0} \mathrm{pb}_{1} \text { Exgrt }_{i t} \mathrm{pb}_{2} \mathrm{Corpt}_{i t} \mathrm{pb}_{3} \mathrm{Gfcfm}_{i t} \mathrm{pb}_{4} \text { Pvrty }_{i t} \\
\mathrm{pb}_{5} \text { Inflt }_{i t} \mathrm{pb}_{6} \operatorname{Trdop}_{i t} \mathrm{pb}_{7} \mathrm{Tlphl}_{i t} \mathrm{pe}_{i t}
\end{gathered}
$$

To start with, we conducted an analysis of Equation (2). Estimating Equation (2) may trigger autocorrelation and endogeneity among the explanatory variables. To eliminate such errors, we first conduct fixed effects (within) estimation. The result of the regression analysis is presented in Table III.

The model fitness test, as depicted by the $p$-value (0.000) and the rho statistics (0.988), are clear indications that the model exhibits high predictive ability, and there is weak possibility of autocorrelation in the estimation. On the explanatory power of each variable, the analyses contained in Table III suggest that four of the six variables estimated are statistically significant at 5 per cent. According to the analyses, civil liberty, rule of law, polity and trade openness play strong deterministic roles in the attraction of FDI to the sampled countries. We test for cross-sectional dependence in the series using the Breusch-Pagan LM test of independence in order to further test for endogeneity in the series. The result of the analyses is presented in Table IV.

The analysis contained in Table IV suggests strong cross-sectional dependency in the series. For instance, the cross-dependence between Russia and India is 87 per cent; India and Mexico 64 per cent; Russia and Mexico 62 per cent; China and India 55 per cent; China and Russia 53 per cent; Russia and Egypt 45 per cent; Brazil and China 41 per cent; 34 per cent between Brazil and Mexico/South Korea; and 27 per cent between Brazil and Nigeria. This is not surprising given the extent of bi/multilateral arrangements between and among the sampled countries. For instance, five of the countries sampled belong to the BRICS multilateral trade group. Further, all the African countries belong to the African Union, while Brazil and Mexico have strengthened their bilateral arrangement. As a result of the

\begin{tabular}{lclrr}
\hline Variables & Coef. & \multicolumn{1}{c}{ SE } & \multicolumn{1}{c}{$t$} & $P \mathrm{~W}|t|$ \\
\hline Logcivbt & 2.635027 & 0.738783 & 3.56 & 0.004 \\
loglawrl & 0.2171967 & 0.2690769 & 0.81 & 0.042 \\
logrglql & -0.132691 & 0.2464289 & -0.54 & 0.295 \\
logpolity & 2.2352 & 1.167485 & 1.91 & 0.040 \\
logtrdop & 1.85619 & 0.7756977 & 2.39 & 0.037 \\
logtlphl & 2.70908 & 1.388332 & 1.95 & 0.241 \\
Cons & -22.19738 & 4.422761 & -5.02 & 0.040
\end{tabular}

Model fitness

$F(6,32)$

$P$ W F

$\rho$

Obs.

10.14

0.000

0.98811048

450
The

machination of

foreign direct investment

Notes: SE adjusted for 3 clusters in I; fraction of variance due to $u \_i$

Table III. Fixed effects (within) regression for model 2

(1970-2014)

'This article is $($ E Emerald Group Publishing and permission has been granted for this version to appear here (please insert the web address here). Emerald does not grant permission for this article to be further copied/distributed or hosted elsewhere without the express permission from Emerald Group Publishing 
DOI to the article: https://doi.org/10.1108/AJEMS-12-2017-0313

\begin{tabular}{|c|c|c|c|c|c|c|c|c|c|c|c|}
\hline \multirow{8}{*}{ AJEMS } & & & & & & & & & & & \\
\hline & & Brazil & China & Egypt & India & Kenya & Mexico & Nigeria & Russia & South Africa & South Korea \\
\hline & Brazil & 1.000 & & & & & & & & & \\
\hline & China & 0.4117 & 1.000 & & & & & & & & \\
\hline & Egypt & 0.2037 & 0.1338 & 1.000 & & & & & & & \\
\hline & India & 0.2209 & 0.5522 & 0.3137 & 1.000 & & & & & & \\
\hline & Kenya & 0.0952 & 0.1875 & 0.0476 & 0.1118 & 1.000 & & & & & \\
\hline & Mexico & 0.3376 & 0.2935 & 0.0762 & 0.6428 & 0.2232 & 1.000 & & & & \\
\hline \multirow{5}{*}{$\begin{array}{l}\text { Table IV. } \\
\text { Breusch-pagan LM } \\
\text { test of independence } \\
\text { for model } 1 \\
(1970-2014)\end{array}$} & Nigeria & 0.2665 & 0.1591 & 0.0152 & 0.1994 & 0.0841 & 0.1692 & 1.000 & & & \\
\hline & Russia & 0.1862 & 0.5285 & 0.4479 & 0.8691 & 0.1243 & 0.6157 & 0.0116 & 1.000 & & \\
\hline & South Africa & 0.2051 & 0.1438 & 0.0225 & 0.2778 & 0.0567 & 0.3075 & 0264 & 0.1604 & 1.000 & \\
\hline & South Korea & 0.3417 & 0.0434 & 0.0161 & 0.2765 & 0.0553 & 0.1947 & 0.3086 & 0.0633 & 0.0085 & 1.000 \\
\hline & Note: Corre & lation ma & atrix of r & esiduals: & $: x^{2}(45)$ & $1 / 4173.0$ & $58, \operatorname{Pr}^{1 / 4}$ & $0.0000(\mathrm{~B}$ & ased on 2 & 45 complete ol & bservations) \\
\hline
\end{tabular}

cross-sectional dependency, we cannot adopt generalised method of moments (GMM) as done in previous studies (Alfaro et al., 2004; Olney, 2013), because the GMM approach assumes cross-sectional independence.

In specific, the ground-breaking work of Parks (1967) emphasised the superiority of feasible generalised least squares (FGLS) over other approaches in this specific instance. More importantly, Baltagi (2008) improves on the work of Hicks (1994) as well as Kmenta (1986) in emphasising the weakness of GMM in estimating data set with strong crosssectional dependency/heteroscedasticity. It must be pointed out therefore, that the FGLS estimation technique is superior in estimating data with fixed effects properties with possibility of autocorrelation in the series. Furthermore, we estimated our models within the valid instrumentation environment to accommodate possible endogeneity. The result of the estimation is presented in Table V.

According to Table $\mathrm{V}$, the goodness of fit test is significant with high predictive ability, and the probability statistics of the Wald Test is significant at 1 per cent. Looking at individual variables, five of the six explanatory variables are statistically significant at 1 per cent and they all inversely related to inflow of FDI, save for regulatory quality $(R g l q l)$ that exhibit proportional progression. In specific, civil liberty, rule of law, polity, trade openness and technology are all statistically significant with strong antithetical coefficients.

In practical terms, the inverse response of rule of law, trade openness and technology are indicative of need for institutional reform and technological improvement. That is, a noticeable improvement in the outlook of these indicators may improve the attractiveness of the sampled countries to inflow of FDI. This is in line with the findings of Rajan and

Table V.

Cross-sectional time-series FGLS Regression

\begin{tabular}{lclrr}
\hline Variables & Coef. & \multicolumn{1}{c}{ SE } & $Z$ & $P W|z|$ \\
\hline Civbt & 0.4800629 & 0.0665768 & 7.21 & 0.000 \\
Lawrl & -0.6541529 & 0.1402438 & -4.66 & 0.000 \\
Rglql & 3.332397 & 0.2644315 & 12.60 & 0.000 \\
Polity & 0.0016333 & 0.0048207 & 0.34 & 0.735 \\
Trdop & -0.1152137 & 0.0003676 & -12.65 & 0.000 \\
Tlphl & -0.1152137 & 0.0153584 & -7.50 & 0.000 \\
Cons & 0.9005788 & 0.2900849 & 3.10 & 0.002 \\
Model fitness & Estimated covariances & 55 & Number of obs. & 450 \\
& Estimated autocorrelations & 0 & Number of groups & 10 \\
& Estimated coefficients & 7 & Time periods & 45 \\
& Wald $X^{2}(6)$ & 315.26 & & \\
\hline
\end{tabular}

'This article is (C) Emerald Group Publishing and permission has been granted for this version to appear here (please insert the web address here). Emerald does not grant permission for this article to be further copied/distributed or hosted elsewhere without the express permission from Emerald Group Publishing 
Zingales (2003) as well as Alfaro et al. (2004) where institutional efficiency was found to expressed strong deterministic properties in the attractive of countries to inflow of FDI. In addition, civil liberty and regulatory quality are proportionally related to FDI. This suggests that the more improved these countries are on improving their regulation as well as civil liberty, the more attractive to FDI they may become.

Although, the FGLS regression suggests deterministic possibility in a pooled estimation, it is considered important to measure the importance and strength of these variables on country-by-country basis. As such, we conduct a seemingly unrelated regression (SUR), which is considered very appropriate based on its superior estimation properties and accuracy in uncovering specific effects of variables on individual countries (Jönsson, 2005). The summary of the SUR estimation is presented in Table AII, while the result of the country-specific SUR estimation is presented in Table VI.

From Table VI, it is evident that civil liberty plays a statistically significant role in the attractiveness of countries like Brazil, Mexico, Nigeria and Russia to inflow of FDI. This negates the findings of Asiedu and Lien (2011) where weak democratic values (or poor civil liberty) is found to attract inflow of FDI. However, the impact of this variable on the attractiveness of China to inflow of FDI is weak. Further analysis suggests that respect for the rule of law is important as a driver of inflow of FDI to Nigeria and South Africa, but not for Kenya. Respect for the rule of law also influences the attractiveness of India inflow of FDI, albeit weakly. This result negates a number of leading previous studies (such as La Porta et al., 2000; Rajan and Zingales, 2003; Laeven and Majnoni, 2004; Kok and Ersoy, 2009) where rule of law is found to play a strong deterministic role in the attractiveness of countries to inflow of FDI.

Another interesting discovery is that regulatory quality is only statistically significant in Russia and South Africa. This finding validates the thesis of Mill's method of residue, in that this variable has largely been ignored in most of the previous studies, of which a few were mentioned in the previous paragraph. Most of the previous studies focussed on regulatory weaknesses (such as the rule of law) rather than the quality of the regulations. In addition, the analysis suggests that polity is only statistically significant in the attractiveness of Mexico to inflow of FDI. This finding once again, negates the findings in previous studies (Paul, 1982; Baer and Rangel, 2001; Loungani and Mauro, 2001; Taylor and Buranelli, 2007; Puffer et al., 2009; Durevall, 2012), where countries such as Brazil, China, India and Russia were found to be attractive to inflow of FDI in the face of their apparent institutional weaknesses.

The two control variables (trade openness and fixed telephone lines) play statistically significant roles. In the trade openness model, we found a strong deterministic impact on the attractiveness of Brazil, Egypt and India to inflow of FDI. The same can be said of South Africa and South Korea. The finding confirms the documented relationship between economic openness and attractiveness of countries to inflow of investment (UNCTAD, 2016). The finding further buttresses the thesis of Townsend's (1979) SVM, essential communication costs within the purview of market efficiency. Here, information arbitrage created by weak trade openness is found to inversely affect the attractiveness of closed economies like China, Egypt, Kenya, Mexico, Nigeria and Russia. In the technology model, we found strong technological capability in Brazil, China, Egypt and Russia help these economies to attract FDI far more than in Nigeria where such capability is lacking.

Analysis of the third model begins with the fixed effects regression, with Haussmann test. This is conducted to influence our choice of either random or fixed effects. The result of the analysis is presented in Table VII.

According to Table VII, the goodness of fit test suggests that fixed effect model is preferred with the $\rho$ statistics of 0.9 . The explanatory power of the fixed effects model is also supported by the $p$-value that is statistically significant at 1per cent. Looking at individual variables, three of the seven variables used are statistically significant. In specific, the gross

\section{machination of foreign direct investment}




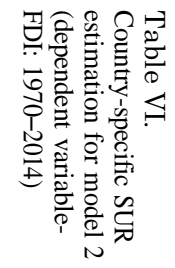

DOI to the article: https://doi.org/10.1108/AJEMS-12-2017-0313

\begin{tabular}{|c|c|c|c|c|c|c|c|c|c|c|c|c|}
\hline \multirow{2}{*}{$\begin{array}{l}\text { Countries } \\
\text { Model Stats }\end{array}$} & \multicolumn{2}{|c|}{ Civbt } & \multicolumn{2}{|c|}{ Lawrl } & \multicolumn{2}{|c|}{ Rglql } & \multicolumn{2}{|c|}{ Polity } & \multicolumn{2}{|c|}{ Trdop } & \multicolumn{2}{|c|}{ Tlphl } \\
\hline & Coeff. & Z_Score & Coeff. & Z_Score & Coeff. & Z_Score & Coeff. & Z_Score & Coeff. & Z_Score & Coeff. & Z_Score \\
\hline Brazil & 0.497275 & $3.57 * * *$ & 1.7560 & 1.79 & 0.447853 & 0.62 & 0.059038 & 1.62 & -0.24399 & $-2.33 * *$ & 0.194930 & $6.23^{* * *}$ \\
\hline Egypt & -0.423034 & -1.22 & -0.001 & -0.00 & 0.340385 & 0.53 & -0.00907 & -0.45 & -0.32797 & $-1.96 * *$ & 0.964639 & $2.78 * * *$ \\
\hline India & -0.049059 & -0.59 & -1.503 & $-1.76^{*}$ & 0.376328 & 0.47 & 0.045388 & 0.97 & 0.031578 & $6.07 * * *$ & -0.013929 & -0.51 \\
\hline Kenya & -0.128485 & -0.98 & -1.560 & $-2.10 * *$ & -0.80059 & -1.13 & -.041414 & -1.00 & 0.005155 & 0.76 & -0.059849 & -1.38 \\
\hline Mexico & 0.309010 & $3.06^{* * * *}$ & -0.178 & -0.52 & -0.27208 & -1.01 & 0.134121 & $3.45^{* * *}$ & 0.045505 & 1.12 & 0.014463 & 0.37 \\
\hline Russia & 1.00812 & $5.71^{* * *}$ & 0.0372 & 0.14 & 0.734884 & $1.91^{* *}$ & 0.001489 & 0.31 & 0.006759 & 0.51 & -0.317573 & $-4.72 * * *$ \\
\hline South Africa & -0.000218 & -0.00 & 1.5243 & $2.43^{* *}$ & 1.22664 & $2.17^{* *}$ & 0.007318 & 1.18 & 0.172022 & $2.03^{* *}$ & -0.010820 & -0.16 \\
\hline South Korea & -0.026419 & -0.54 & 0.4081 & 0.83 & 0.035978 & 0.12 & 0.001707 & 0.50 & 0.001088 & $3.75^{* * *}$ & -0.067166 & -0.86 \\
\hline Notes: $\{$ Em & is are plac & ${ }^{* *} p \mathrm{O}$ & $* * * n$ & $1\} . * p$ & ;**po 0 & $* * p 0$ & & & & & & \\
\hline
\end{tabular}

'This article is $(\mathcal{C}$ Emerald Group Publishing and permission has been granted for this version to appear here (please insert the web address here). Emerald does not grant permission for this article to be further copied/distributed or hosted elsewhere without the express permission from Emerald Group Publishing 
DOI to the article: https://doi.org/10.1108/AJEMS-12-2017-0313

\begin{tabular}{|c|c|c|c|c|c|}
\hline Variables & Coef. & SE & $t$ & $P \mathrm{~W}|t|$ & \\
\hline Exgrt & 0.532851 & 0.5544641 & 0.96 & 0.337 & foreign direct \\
\hline Corpt & 0.0001099 & 0.0004863 & 0.23 & 0.821 & \\
\hline Gfcfm & 0.0741203 & 0.0207579 & 3.57 & 0.00 & \\
\hline Pvrty & -6.842494 & 1.358921 & -5.04 & 0.00 & \\
\hline Inflt & -0.0004111 & 0.0006552 & -0.63 & 0.531 & \\
\hline Trdop & -0.0058047 & 0.0016927 & -3.43 & 0.001 & \\
\hline Tlphl & 0.0164381 & 0.0575213 & 0.29 & 0.775 & \\
\hline Cons & 5.688607 & 1.325053 & 4.29 & 0.000 & \\
\hline Model fitness & & & & & $\begin{array}{l}\text { Table VII. } \\
\text { Fixed effects }\end{array}$ \\
\hline$F(7,433)$ & 13.91 & $P W F$ & 0.000 & & $\begin{array}{l}\text { Fixed eirects (Witnin) } \\
\text { regression for model } 3\end{array}$ \\
\hline$\rho$ & 0.859802 & Obs. & 450 & & (dependent variable - \\
\hline \multicolumn{5}{|c|}{ Notes: SE adjusted for 3 clusters in I; fraction of variance due to $\mathrm{u} \_\mathrm{i}$} & FDI) (1970-2014) \\
\hline
\end{tabular}

fixed capital formation model indicates direct and positive relationship with FDI, albeit with weak coefficient. Conversely in the poverty, we found a strong inverse relationship with FDI, while trade openness model also indicates statistically significant but weak coefficient. This analysis suggests that weak productivity gains informed by poverty does discourage flow of FDI in the pooled estimation. To ally the fear of autocorrelation and endogeneity, we conduct cross-dependence estimation as done for the other models and the result is presented in Table VIII.

Table VIII documents the possibility of cross-sectional dependence in the series. For instance, there is a cross-sectional dependency of 52 per cent between Egypt and Russia; 50 per cent between Mexico and South Africa; 46 per cent between Brazil and China; 39 per cent between India and Russia/Egypt; 21 per cent between Brazil and Nigeria; and 20 per cent between Brazil and Egypt. This cross-sectional dependency suggests the possibility of autocorrelation across cross-sections, which influences our decision to adopt FGLS (in tandem with the previous estimations). The result of the regression analysis is presented in Table IX.

From Table IX, the goodness of fit statistics indicate that the model is stable with high predictive power. The Wald $\mathrm{X}^{2}$ test suggests stability and the $p$-value is significant at 1 per cent. Looking at individual variables, five of the seven explanatory variables are statistically significant, of which three bear inverse relationship with the dependent variable. Exchange rates differentials positively influences inflow of FDI, in the same way as gross fixed capital

\begin{tabular}{|c|c|c|c|c|c|c|c|c|c|c|c|}
\hline & Brazil & China & Egypt & India & Kenya & Mexico & Nigeria & Russia & South Africa & $\begin{array}{l}\text { South } \\
\text { Korea }\end{array}$ & \\
\hline Brazil & 1.000 & & & & & & & & & & \\
\hline China & 0.4590 & 1.000 & & & & & & & & & \\
\hline Egypt & -0.2003 & -0.0800 & 1.000 & & & & & & & & \\
\hline India & -0.0375 & 0.1401 & 0.3885 & 1.000 & & & & & & & \\
\hline Kenya & -0.0432 & 0.0237 & 0.1566 & 0.1185 & 1.000 & & & & & & \\
\hline Mexico & -0.1289 & -0.2108 & 0.0015 & -0.2390 & -0.1061 & 1.000 & & & & & \\
\hline Nigeria & -0.2076 & -0.0574 & 0.0440 & -0.1223 & 0.2106 & -0.0368 & 1.000 & & & & Table \\
\hline Russia & -0.4130 & -0.3624 & 0.5162 & 0.3878 & 0.0915 & 0.2305 & -0.0078 & 1.000 & & & Breusch-pagan LM \\
\hline South Africa & -0.0790 & 0.0664 & 0.0475 & 0.1443 & 0.0117 & 0.4958 & 0.0907 & 0.1894 & 1.000 & & test of independence \\
\hline South Korea & 0.1855 & 0.2263 & 0.0528 & -0.1715 & -0.0495 & 0.1596 & 0.0168 & 0.0086 & 0.0022 & 1.000 & for model 3 \\
\hline Note: Correla & ation matr & rix of resid & duals: $x^{2}$ & (45) $1 / 488$ & 3.149, $\operatorname{Pr} 1 / 4$ & 40.0001 (b & sed on 45 & 5 comple & lete observat & & \\
\hline
\end{tabular}

'This article is $($ E Emerald Group Publishing and permission has been granted for this version to appear here (please insert the web address here). Emerald does not grant permission for this article to be further copied/distributed or hosted elsewhere without the express permission from Emerald Group Publishing 
DOI to the article: https://doi.org/10.1108/AJEMS-12-2017-0313

AJEMS formation and purchasing power (market size) as determined by poverty level. These findings are in line with previous studies (Alfaro et al., 2004). Conversely, instruments of trade restriction and low technological capability are found to negatively influence the attractiveness of sampled countries to inflow of FDI. Surprisingly, corruption and inflation appear not to influence investors' decisions. This negates the finding of La Porta et al. (2000) wherein corruption was found to play a strong deterministic role in country's attractiveness.

To determine the specific impact of these variables on each of the countries under consideration, the SUR estimation is repeated in this model. The summary of the estimation is presented in Table AIII, while the result of the estimation appears in Table X.

From the table, we found strong evidence in support the positive explanatory properties of exchange rates on inflow of FDI to Brazil, India, Russia and Nigeria, while other countries in our sample are found to be less reactive. Further, corruption is found to discourage the attractiveness of South Korea to inflow of FDI, whereas it augments the attractiveness of China and Nigeria very strongly. Evidence also suggests that infrastructural development positively influences the attractiveness of Brazil, Egypt, Russia and South Korea to inflow of FDI, while the poverty level in India, Russia and South Africa appear to be a strong deterrent to inflow of FDI. Conversely, prevalence of poverty evidently augments FDI attractiveness of Nigeria. This finding is in line with the study of Taylor and Buranelli (2007) where strong correlation was established between graft and attractiveness of Brazil to FDI inflow. However, in the face of this congenial similarity, Nigeria remains unattractive to industrial-orientated FDI.

Further, inflation is found to hinder the attractiveness of Brazil to inflow of FDI as found by Alfaro et al. (2004), while it augments the attractiveness of India. In addition, lack of trade openness in Brazil and Russia (and in all African countries, save for South Africa) negatively influences their attractiveness, while such liberalisation augments the attractiveness of Mexico, South Africa and South Korea. Similarly, technological advancement in Brazil and China are strong positive enhancers of the attractiveness of the countries to inflow of FDI, while low technological capacity of African countries constricts their attractiveness in this regard.

Conclusion and policy implications

This study was set out to investigate the determinants of FDI inflow to some emerging markets. The study benefit from diverse institutional variables, most of which has been ignored in previous studies. In addition, we remodelled Cobb and Douglass production function to capture productivity gains as a possible determinant of countries' attractiveness to FDI inflow. The study is particularly important because it did not only

Table IX.

Cross-sectional timeseries FGLS

regression for model 3 (dependent

variable-FDI)

\begin{tabular}{lllll}
\hline Variables & \multicolumn{1}{c}{ Coef. } & \multicolumn{1}{c}{ SE } & \multicolumn{1}{c}{$P \mathrm{~W}|z|$} \\
\hline Exgrt & 2.571226 & 0.1814553 & 14.17 & 0.000 \\
Corpt & -0.0000583 & 0.0002074 & -0.28 & 0.779 \\
Gfcfm & 0.270138 & 0.0123742 & 21.83 & 0.000 \\
Pvrty & 4.441347 & 0.3857588 & 11.51 & 0.000 \\
Inflt & -0.0001336 & 0.0003396 & -0.39 & 0.694 \\
Trdop & -0.0078116 & 0.0004464 & -17.50 & 0.000 \\
Tlphl & -0.1753048 & 0.0114691 & -15.28 & 0.000 \\
Cons & -6.156642 & 0.487404 & -12.63 & 0.000 \\
Model fitness & Estimated covariances & 55 & Number of obs. & 450 \\
& Estimated autocorrelations & 0 & Number of groups & 10 \\
& Estimated coefficients & 8 & Time periods & 45 \\
& Wald X ${ }^{2}(6)$ & 726.03 & Prob. Wx & 0.0000
\end{tabular}

'This article is (C) Emerald Group Publishing and permission has been granted for this version to appear here (please insert the web address here). Emerald does not grant permission for this article to be further copied/distributed or hosted elsewhere without the express permission from Emerald Group Publishing 
DOI to the article: https://doi.org/10.1108/AJEMS-12-2017-0313

\begin{tabular}{|c|c|c|c|c|c|c|c|c|c|c|c|c|c|c|}
\hline \multirow{2}{*}{$\begin{array}{l}\text { Countries } \\
\text { Model } \\
\text { elements }\end{array}$} & \multicolumn{2}{|c|}{ Exgrt } & \multicolumn{2}{|c|}{ Corpt } & \multicolumn{2}{|c|}{ Gfcfm } & \multicolumn{2}{|c|}{ Pvrty } & \multicolumn{2}{|c|}{ Inflt } & \multicolumn{2}{|c|}{ Trdop } & \multicolumn{2}{|c|}{ Tlphl } \\
\hline & Coeff. & Z_Score & Coeff. & Z_Score & Coeff. & Z_Score & Coeff. & Z_Score & Coeff. & Z_Score & Coeff. & Z_Score & Coeff. & Z_Score \\
\hline Brazil & 0.856932 & $3.28 * * *$ & -0.03289 & -1.54 & 0.105330 & $2.88^{* * *}$ & 2.996796 & 1.30 & -0.00040 & $-2.06 * *$ & -0.322135 & $-2.24 * *$ & 0.102550 & $2.34 * *$ \\
\hline China & -0.669136 & -0.08 & 0.589450 & $3.11^{* * *}$ & -0.15564 & -1.41 & -15.5496 & -1.38 & 0.121084 & 0.60 & -.0402842 & -0.35 & 6.953722 & $3.71^{* * *}$ \\
\hline Egypt & 2.958917 & 1.19 & -0.046259 & -0.96 & 0.493015 & $4.04^{* * *}$ & 1.428176 & 0.36 & 0.061946 & 1.13 & -0.303036 & -0.68 & -1.02480 & $-2.30 * *$ \\
\hline India & 1.582509 & $2.20 * *$ & 0.007483 & 1.04 & 0.123674 & 1.24 & -4.00958 & $-3.58 * * *$ & 0.050974 & $2.43^{* *}$ & -0.004396 & -0.48 & -0.04912 & $-1.79 *$ \\
\hline Kenya & 0.606227 & 0.18 & 0.008934 & 1.02 & -0.27257 & -0.82 & -0.12350 & -0.02 & 0.005696 & 0.12 & -0.000607 & -0.15 & -0.044352 & -0.70 \\
\hline Mexico & -3.355661 & -1.37 & 0.014974 & 1.42 & -0.02636 & -0.36 & 8.882164 & $1.71 *$ & -0.03703 & -1.04 & 0.166506 & $2.67 * * *$ & -0.05594 & -1.06 \\
\hline Nigeria & -13.65587 & $-1.96 * *$ & 0.072005 & $2.52^{* *}$ & 1.762294 & 1.10 & 28.12295 & $2.17 * *$ & -0.02687 & -0.50 & 0.021302 & $1.61^{*}$ & 0.002157 & 0.01 \\
\hline Russia & 1.450474 & $1.96 * *$ & -0.000005 & -0.13 & 0.070129 & $3.16^{* * *}$ & -6.13984 & $-3.55^{* * *}$ & -0.00265 & -0.09 & -0.037834 & $-2.42 * *$ & -0.06689 & -0.78 \\
\hline South Africa & 2.571387 & $1.86^{*}$ & 0.006521 & 0.35 & 0.153711 & 1.02 & -11.2715 & $-2.79 * * *$ & 0.003275 & 0.05 & 0.153606 & $2.00 * *$ & -0.08402 & -0.69 \\
\hline South Korea & -0.433321 & -0.99 & -0.011105 & $-4.72 * * *$ & 0.014093 & $3.05^{* * *}$ & 1.217204 & 1.34 & 0.003121 & 0.22 & 0.001281 & $4.59 * * *$ & 0.023355 & 0.21 \\
\hline
\end{tabular}

Table X. Country-specific SUR estimation for model 3 (dependent variable- FDI: 1970-2014)

'This article is $(\subset$ Emerald Group Publishing and permission has been granted for this version to appear here (please insert the web address here). Emerald does not grant permission for this article to be further copied/distributed or hosted elsewhere without the express permission from Emerald Group Publishing 
DOI to the article: https://doi.org/10.1108/AJEMS-12-2017-0313

AJEMS cover the largest emerging economies globally, the sample is widely representative of emerging markets globally. In addition, the methodological novelty of the study is distinctive from documented literature.

From the analyses, regulatory model suggests that moderate civil liberty is required to attract inflow of FDI. This is particularly true for all the emerging markets in our sample. This finding is indicative that government efforts towards the improvement of this important fundament human right would improve the attractiveness of these emerging economies, especially countries in Africa, to FDI inflow. Further evidence from the model suggests that Africa is largely backward technologically, which discourages inflow of FDI to most of the African countries in our sample; which necessitates technological capacity building to improve the attractiveness of countries like Nigeria to FDI inflow. Furthermore, the capital gains model reiterates the importance poverty alleviation interventions in order to improve the purchasing power of the people and ultimately improve the attractiveness of a country like South Africa to FDI inflow.

This study also suggests that African countries should liberalise their markets to attract FDI. Trade liberalisation that is underpinned by expansive industrialisation, has been economically viable in India, China and Brazil. This is a good indication that Africa may achieve economic growth through a well-guided liberalisation agenda. The need for infrastructural development in Africa is also recorded towards attracting FDI through capital-gains nexus, lending from South Korea, Russia and Brazil. In conclusion, Emerging African economies may develop and alleviate poverty through institutional reinforcement and enhancement of productivity capital gains in a way that improves their attractiveness to FDI inflow.

\section{Note}

1. Estimations in balanced panel environments are largely more stable than in unbalanced panels (Baltagi, 2008).

\section{References}

Aizenman, J. (2003), "Volatility, employment and the patterns of FDI in emerging markets", Journal of Development Economics, Vol. 72 No. 2, pp. 585-601.

Akinkugbe, O. (2005), "A two-part econometric analysis of foreign direct investment flows to Africa", Journal of World Trade, Vol. 39 No. 5, pp. 907-923.

Alfaro, L., Chanda, A., Kalemli-Ozcan, S. and Sayek, S. (2004), "FDI and economic growth: the role of local financial markets", Journal of International Economics, Vol. 64 No. 1, pp. 89-112.

Aregbeshola, R.A. (2016), "The role of local financial market on economic growth - a sample of three African economic groupings", African Journal of Economic and Management Studies, Vol. 7 No. 2, pp. 225-240.

Asiedu, E. and Lien, D. (2011), "Democracy, foreign direct investment and natural resources", Journal of International Economics, Vol. 84 No. 1, pp. 99-111.

Ayaydin, H. and Baltaci, N. (2013), "Corruption, banking sector, and market development: a panel data analysis", European Journal of Research on Education, Human Resources Management, pp. 94-99.

Baer, W. and Rangel, G.B. (2001), "Foreign investment in the age of globalisation: the case of Brazil", Latin American Business Review, Vol. 2 Nos 1-2, pp. 83-99.

Baltagi, B.H. (2008), Econometrics Analysis of Panel Data, 4th ed., John Willey and Sons, Chichester.

Bénassy-Quéré, A., Coupet, M. and Mayer, T. (2007), "Institutional determinants of foreign direct investment", The World Economy, Vol. 30 No. 5, pp. 764-782.

Bruce, K. and Chang, S.J. (1991), "Technical capabilities and Japanese foreign direct investment in the United States", Review of Economic and Statistics, Vol. 73 No. 3, pp. 401-413. 
DOI to the article: https://doi.org/10.1108/AJEMS-12-2017-0313

Chakrabarti, A.A. (2003), "Theory of the spatial distribution of foreign direct investment", International Review of Economics \& Finance, Vol. 12 No. 2, pp. 149-169.

Chousa, J.P., Valdlamannati, K.C. and Tamazian, A. (2008), "Does growth and quality of markets drive foreign capital? The case of cross-border mergers and acquisitions from leading emerging economies", Working Paper No. 911, William Davidson Institute, Ankara.

Chung, W. (2001), "Identifying technology transfer in foreign direct investment: influence of industry conditions and investing firm motives", Journal of International Business Studies, Vol. 32 No. 2, pp. 211-229.

Cobb, C.W. andDouglas, P.H.(1928), "A theory of production”, The American Economic Review, Vol.18 No. 1, pp. 139-165.

Durevall, D. (2012), "The dynamics of chronic inflation in Brazil, 1968-1985", Journal of Business and Economic Statistics, Vol. 16 No. 4, pp. 423-432.

Hicks, A.M. (1994), "Introduction to pooling", in Janoski, T. and Hicks, A. (Eds), The Comparative Political Economy of the Welfare State, Cambridge University Press, Cambridge, pp. 169-188.

Horak, R. (2007), Telecommunications and Data Communications Handbook, Wiley Publishers, New Jersey, NJ.

Huang, N.-Fu. and Wang, Y.-T. (1995), "Wireless LAN emulation over ATM networks", in Puigjaner, R. (Ed.), High Performance Networking VI, IFIP Sixth International Conference on High Performance Network, Springer, Boston, MA, pp. 71-84.

Jönsson, K. (2005), "Cross-sectional dependency and size distortion in a small-sample homogenous panel data unit root test", Oxford Bulletin of Economic Statistics, Vol. 67 No. 3, pp. 369-392.

Kmenta, J.(1986), Elements of Econometrics, 2nd ed., McMillan, New York, NY.

Kok, R. and Ersoy, B.A. (2009), "Analysis of FDI determinants in developing countries", International Journal of Social Economics, Vol. 36 Nos 1-2, pp. 105-123.

Kolstad, I. and Villanger, E. (2008), "Foreign direct investment in the Caribbean", Development Policy Review, Vol.26 No. 1, pp. 79-89.

La Porta, R., Lopez-de-Silanes, F., Shleifer, A. and Vishny, R. (2000), "Investor protection and corporate governance", Journal of Financial Economics, Vol. 58 Nos 1-2, pp. 3-27.

Laeven, L. and Majnoni, G. (2004), “Does judicial efficiency lower the cost of credit?”, Journal of Banking and Finance, Vol. 29 No. 7, pp.1791-1812.

Lee, C.-C. and Chang, C.-P. (2009), "FDI, financial development and economic growth: international evidence", Journal of Applied Economics, Vol. 12 No. 2, pp. 249-271.

Loungani, P. and Mauro, P. (2001), "Capital flight from Russia”, The World Economy, Vol. 24 No. 5, pp. 689-706.

Mill, J.S.A. (1854), "System of logic, ratiocinative and inductive", The North American Review, Vol. 78 No. 162 , pp. 85-105.

Olney, W.B. (2013), "A race to the bottom? Employment protection and foreign direct investment", Journal of International Economics, Vol. 91 No. 2, pp. 191-203.

Parks, R.W. (1967), "Efficient estimation of a system of regression equations when disturbances are both serially and contemporaneously correlated",Journal of the American Statistical Association, Vol. 62 No. 318, pp. 500-509.

Paul, G.R. (1982), "Russian national income, 1885-1913", Cambridge University Press, Cambridge.

Puffer, S.M., McCarthy Daniel, J. and Boisot Max, H. (2009), "Entrepreneurship in Russia and China: the impact of formal institutional voids", Entrepreneurship Theory and Practice, Vol. 34 No. 3, pp. 441-467.

Rajan, R.G. and Zingales, L. (2003), "The great reversals: the politics of financial development in the twentieth century", Journal of Financial Economics, Vol. 69 No. 1, pp. 5-50.

Robert, P. and Papanastassiou, M. (1999), "Overseas R\&D and the strategic evolution of MNEs: evidence from laboratories in the UK", Research Policy, Vol. 28 No. 1, pp. 23-41.

'This article is (C) Emerald Group Publishing and permission has been granted for this version to appear here (please insert the web address here). Emerald does not grant permission for this article to be further copied/distributed or hosted elsewhere without the express permission from Emerald Group Publishing 
DOI to the article: https://doi.org/10.1108/AJEMS-12-2017-0313

AJEMS Sen, A. (1999), Development as Freedom, Oxford University Press, London.

Stiglitz, J.E. and Charlton, A. (2005), Fair Trade for All, Oxford Press, New York, NY.

Taylor, M.M. and Buranelli, V.C. (2007), "Ending up in pizza: accountability as a problem of institutional arrangement in Brazil", Latin American Politics and Society, Vol.49 No. 1, pp. 59-87.

Townsend, R.M. (1979), "Optimal contracts and competitive markets with costly state verification", Journal of Economic Theory, Vol. 21 No. 2, pp. 265-293.

United Nations Conference on Trade and Development (2013), "World Investment Report - Global Value Chains: Investment and Trade for Development", UNCTAD, New York, NY and Geneva.

United Nations Conference on Trade and Development (UNCTAD) (2016), "Global Investment Trends Monitor", No. 22, The United Nations, New York, NY.

Vladimir, A., Tomislav, G. and Irena, R. (2013), "The relationship between the stock market and foreign direct investment in Croatia: evidence from VAR and cointegration analysis", Journal of Financial Theory and Practice, Vol.57 No.1,pp.109-126. 
DOI to the article: https://doi.org/10.1108/AJEMS-12-2017-0313

Appendix 1

$\underline{\text { Variables }}$

FDI

Gross fixed capital formation

Strength of legal rights

Exchange rates

Fixed telephone subscriptions per 100 people

Inflation

Polity score

Civilliberty

\section{Definition}

Foreign direct investment refers to direct investment equity flows in an economy. It is the sum of equity capital, a category of cross-border investment associated with a resident in one economy having control or a significant degree of influence on the management of an enterprise that is resident in another economy. Ownership of 10 per cent or more of the ordinary shares of voting stock is the criterion for determining the existence of a direct investment relationship. This series shows net outflows of investment from the reporting economy to the rest of the world. Data are in current US dollars Gross fixed capital formation (formerly gross domestic fixed investment) includes land improvements (fences, ditches, drains, and so on); plant, machinery, and equipment purchases; and the construction of roads, railways, and the like, including schools, offices, hospitals, private residential dwellings, and commercial and industrial buildings. According to the 1993 SNA, net acquisitions of valuables are also considered capital formation. Data are in current US dollars

Strength of legal rights index measures the degree to which collateral and bankruptcy laws protect the rights of borrowers and lenders and thus facilitate lending. The index ranges from 0 to 12 , with higher scores indicating that these laws are better designed to expand access to credit

The exchange rate is the price of one currency in terms of another. Official exchange rates and exchange rate arrangements are established by governments. Other exchange rates recognised by governments include market rates, which are determined largely by legal market forces, and for countries with multiple exchange arrangements, principal rates, secondary rates, and tertiary rates

Fixed telephone subscriptions refers to the sum of active number of analogue fixed telephone lines, voice-over-IP (VoIP) subscriptions, fixed wireless local loop (WLL) subscriptions, ISDN voice-channel equivalents and fixed public payphones Inflation as measured by the annual growth rate of the GDP implicit deflator shows the rate of price change in the economy as a whole. The GDP implicit deflator is the ratio of GDP in current local currency to GDP in constant local currency This is a general institutionalized authority traits that characterize Centre for Systemic a distinct polity (a polity distinguished by distinct and identifiable Peace (INSCR) regime changes at both its inception and its termination); noticeable changes in authority traits during the lifespan of a distinct policy A polity that cannot exercise relatively effective authority over at least 50 per cent of its established territory is necessarily considered to be in a condition of "state failure"

Countries and territories are ranked based on the extent to which they enjoy a wide range of civil liberties, including freedoms of expression, assembly, association, education, and religion. They have an established and generally fair legal system that ensures the rule of law (including an independent

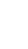

Sources

World development indicators (The World Bank platform) foreign direct investment 
DOI to the article: https://doi.org/10.1108/AJEMS-12-2017-0313

AJEMS

\begin{tabular}{|c|c|c|}
\hline Variables & Definition & Sources \\
\hline & $\begin{array}{l}\text { judiciary), allow free economic activity, and tend to strive for } \\
\text { equality of opportunity for everyone, including women and } \\
\text { minority groups }\end{array}$ & \\
\hline Political rights & $\begin{array}{l}\text { Countries and territories are ranked on the extent to they enjoy a } \\
\text { wide range of political rights, including free and fair elections. } \\
\text { Candidates who are elected actually rule, political parties are } \\
\text { competitive, the opposition plays an important role and enjoys } \\
\text { real power, and the interests of minority groups are well } \\
\text { represented in politics and government }\end{array}$ & \\
\hline $\begin{array}{l}\text { Political } \\
\text { durability }\end{array}$ & $\begin{array}{l}\text { Countries and territories are ranked based on the extent to } \\
\text { which an elected leader fulfils the electoral mandate through } \\
\text { completion of terms of office. Political durability does not } \\
\text { accommodate military intervention in partisan politics and } \\
\text { forceful military intervention }\end{array}$ & \\
\hline Poverty level & $\begin{array}{l}\text { Poverty Measures provide a national accounts based approach } \\
\text { to calculating poverty that differs from the World Bank poverty } \\
\text { estimates. The measures estimate and provide forecasts of the } \\
\text { number of people living in households earning or spending } \\
\text { below a poverty line of US } \$ 2 \text { and US } \$ 5 \text { ( } 2005 \text { PPP USD) per } \\
\text { person per day, and the resources required to bring each } \\
\text { individual to this threshold }\end{array}$ & $\begin{array}{l}\text { Brookings } \\
\text { Development Aid and } \\
\text { Governance Indicators }\end{array}$ \\
\hline $\begin{array}{l}\text { Freedom from } \\
\text { corruption }\end{array}$ & $\begin{array}{l}\text { The extent to which incidence of corruption is tamed. The index } \\
\text { measures the incidence and prevalence of corruption, especially } \\
\text { the possibility of government officials soliciting illegal payment } \\
\text { or bribes before they discharge their official duties }\end{array}$ & $\begin{array}{l}\text { Index of Economic } \\
\text { Freedom (Econ Stats) }\end{array}$ \\
\hline $\begin{array}{l}\text { Regulatory } \\
\text { quality }\end{array}$ & $\begin{array}{l}\text { Regulatory quality captures perceptions of the ability of the } \\
\text { government to formulate and implement sound policies and } \\
\text { regulations that permit and promote private sector development }\end{array}$ & $\begin{array}{l}\text { World governance } \\
\text { indicators }\end{array}$ \\
\hline Rule of law & $\begin{array}{l}\text { Rule of law captures perceptions of the extent to which agents have } \\
\text { confidence in and abide by the rules of society, and in particular the } \\
\text { quality of contract enforcement, property rights, the police, and the } \\
\text { courts, as well as the likelihood of crime and violence }\end{array}$ & \\
\hline Property rights & $\begin{array}{l}\text { Property rights, including financial assets as clearly and } \\
\text { strongly defined in related laws. The extent to which these } \\
\text { rights are recognised and protected by law }\end{array}$ & $\begin{array}{l}\text { Economic Freedom of } \\
\text { the World }\end{array}$ \\
\hline $\begin{array}{l}\text { Strength of legal } \\
\text { rights }\end{array}$ & $\begin{array}{l}\text { Strength of legal rights index measures the degree to which } \\
\text { collateral and bankruptcy laws protect the rights of borrowers } \\
\text { and lenders and thus facilitate lending. The index ranges from } 0 \\
\text { to 12, with higher scores indicating that these laws are better } \\
\text { designed to expand access to credit }\end{array}$ & \\
\hline Trade openness & $\begin{array}{l}\text { Taxes and tariffs that are specifically designed to discourage } \\
\text { international trade participation. This categorisation includes } \\
\text { the use of subsidies to protect local manufacturing facilities }\end{array}$ & \\
\hline
\end{tabular}

Table AI. the use of subsidies to protect local manufacturing facilities

'This article is $($ Emerald Group Publishing and permission has been granted for this version to appear here (please insert the web address here). Emerald does not grant permission for this article to be further copied/distributed or hosted elsewhere without the express permission from Emerald Group Publishing 
DOI to the article: https://doi.org/10.1108/AJEMS-12-2017-0313

Appendix 2

The

machination of

foreign direct investment

\begin{tabular}{|c|c|c|c|c|c|c|c|}
\hline Equation & Obs & Parms & RMSE & $R^{2}$ & $x^{2}$ & $P$ & investment \\
\hline fdi1 & 45 & 6 & 0.9314151 & 0.8221 & 243.06 & 0.0000 & \\
\hline fdi2 & 45 & 6 & 5.244041 & 0.9425 & 827.52 & 0.0000 & \\
\hline fdi3 & 45 & 6 & 2.005735 & 0.6121 & 75.91 & 0.0000 & \\
\hline fdi4 & 45 & 6 & 0.5009901 & 0.7639 & 163.91 & 0.0000 & \\
\hline fdi 5 & 45 & 6 & 0.4960414 & 0.6168 & 74.26 & 0.0000 & \\
\hline fdi6 & 45 & 6 & 0.5336729 & 0.9280 & 591.26 & 0.0000 & \\
\hline fdi7 & 45 & 6 & 1.794812 & 0.7235 & 119.70 & 0.0000 & \\
\hline fdi8 & 45 & 6 & 0.618263 & 0.8558 & 293.07 & 0.0000 & Table AII. \\
\hline fdi9 & 45 & 6 & 0.9737069 & 0.5703 & 61.07 & 0.0000 & SUR summary table \\
\hline fdi10 & 45 & 6 & 0.3296261 & 0.8238 & 215.19 & 0.0000 & (model I) \\
\hline
\end{tabular}

Appendix 3

\begin{tabular}{|c|c|c|c|c|c|c|c|}
\hline Equation & Obs & Parms & RMSE & $R^{2}$ & $x^{2}$ & $P$ & \\
\hline fdi1 & 45 & 7 & 0.8133406 & 0.8643 & 304.70 & 0.0000 & \\
\hline fdi2 & 45 & 7 & 5.043502 & 0.9468 & 867.02 & 0.0000 & \\
\hline fdi3 & 45 & 7 & 1.645653 & 0.7389 & 132.24 & 0.0000 & \\
\hline fdi 4 & 45 & 7 & 0.3770062 & 0.8663 & 311.71 & 0.0000 & \\
\hline fdi5 & 45 & 7 & 0.5138005 & 0.5889 & 63.99 & 0.0000 & \\
\hline fdi6 & 45 & 7 & 0.4967272 & 0.9376 & 701.44 & 0.0000 & \\
\hline fdi7 & 45 & 7 & 1.735462 & 0.7415 & 140.00 & 0.0000 & \\
\hline fdi8 & 45 & 7 & 0.5095453 & 0.9021 & 448.73 & 0.0000 & Table AIII. \\
\hline fdi9 & 45 & 7 & 0.9057039 & 0.6282 & 76.35 & 0.0000 & SUR summary table \\
\hline fdi10 & 45 & 7 & 0.2698029 & 0.8819 & 377.82 & 0.0000 & (model 2) \\
\hline
\end{tabular}

Corresponding author

Rafiu Adewale Aregbeshola can be contacted at: aregbra@unisa.ac.za

'This article is $(\mathcal{C}$ Emerald Group Publishing and permission has been granted for this version to appear here (please insert the web address here). Emerald does not grant permission for this article to be further copied/distributed or hosted elsewhere without the express permission from Emerald Group Publishing 